\title{
System Validation Tests for an SOFC Power System at
} \section{INER}

\author{
Shih-Kun Lo, Wen-Tang Hong, Hsueh-I Tan, Huan-Chan Ting, Ting-Wei Liu and Ruey-Yi Lee
} Institute of Nuclear Energy Research No. 1000 Wenhua Road, Longtan District Taoyuan City / Taiwan (R.O.C.)

\begin{abstract}
This research presents the results of system validation tests for an SOFC power system. In the study, the system was heated up without electric device, i.e., the fuel providing the required thermal energy through an integrated BOP (balance of plant). The ex-situ experiments, without an SOFC stack installed in the system, were first conducted to investigate the operability of a BOP apparatus. It was found that the BOP possessed high conversion rates for both steam reforming and water gas shift reactions. The total fuel concentration of hydrogen and carbon monoxide from the reformer was around $91.2 \%$. The system validation tests showed that, with the natural gas as fuel, the output power from the stack reached to 1,060 $\mathrm{W}$, while the fuel utilization efficiency and electrical efficiency were $67.16 \%$ and $45.0 \%$, respectively. A steady 600 -hour system operation test was carried out at an average system temperature of $694^{\circ} \mathrm{C}$. Of which, a 36-cell stack was employed for the test. Meanwhile, the current, voltage and output power were $26 \mathrm{~A}, 32.3 \mathrm{~V}$ and $840 \mathrm{~W}$, respectively, and its electrical efficiency was around $33.4 \%$.
\end{abstract}

Key words: SOFC power system, fuel utilization, electrical efficiency.

\section{Introduction}

SOFC is considered as a very promising technology of energy conversion due to its high electrical efficiency. Moreover, SOFC offers fuel flexibility and its fuel processing is simpler than other types of fuel cells. Ro et al. [1] demonstrated the performance of 20 $\mathrm{kW}$ SOFC system with natural gas for $4,000 \mathrm{~h}$. The results indicated that insufficient desulfurization of the N.G. and higher Cr-evaporation increase the system degradation. Performance for an SOFC power system without the steam reforming and the anode off-gas recycling might be $16 \%$ less than that of a system with anode gas recycling. Moreover, the electrical and thermal efficiencies were mainly influenced by fuel utilization and anode off-gas recirculation ratios [2]. Halinen et al. [3] performed the endurance testing for a $5 \mathrm{~kW}$ SOFC system fueled with the natural gas. The experimental results indicated that the reformer and heat exchangers performed satisfactorily over a period of 7,000 hours. In 2012 [4], they presented that high steam to carbon ratios and/or recycling ratios could

Corresponding author: Ruey-Yi Lee, Ph. D., research field: solid oxide fuel cell. prevent system damage due to coking. Lee et al. [5] designed and optimized a combined steam reforming and SOFC system based on an anode off-gas recycling approach. It showed that the optimal system efficiency was obtained using a stack operating temperature of $900{ }^{\circ} \mathrm{C}$, a steam-to-carbon ratio of more than 3, maximum $\mathrm{CO}_{2}$ capture, and minimum anode off-gas recirculation. Wahl et al. [6] presented that anode gases were not pure methane and the contents of anode gas might vary. As gases with methane content $<90 \%$, the system lifetime was not fulfilled and the electrical efficiency was reduced.

The INER [7] has recently developed a kilowatt SOFC power system, which comprises a fuel cell stack, porous media afterburner/reformer, heat exchangers, water supply system, data acquisition and control system. In this study, experimental tests are carried out to investigate the system performance and operating characteristics.

\section{Experiments}

Fig. 1 presents a schematic of SOFC system experiment apparatus, which includes the gas supply system, BOPs (balance of plants), power conditioner, 


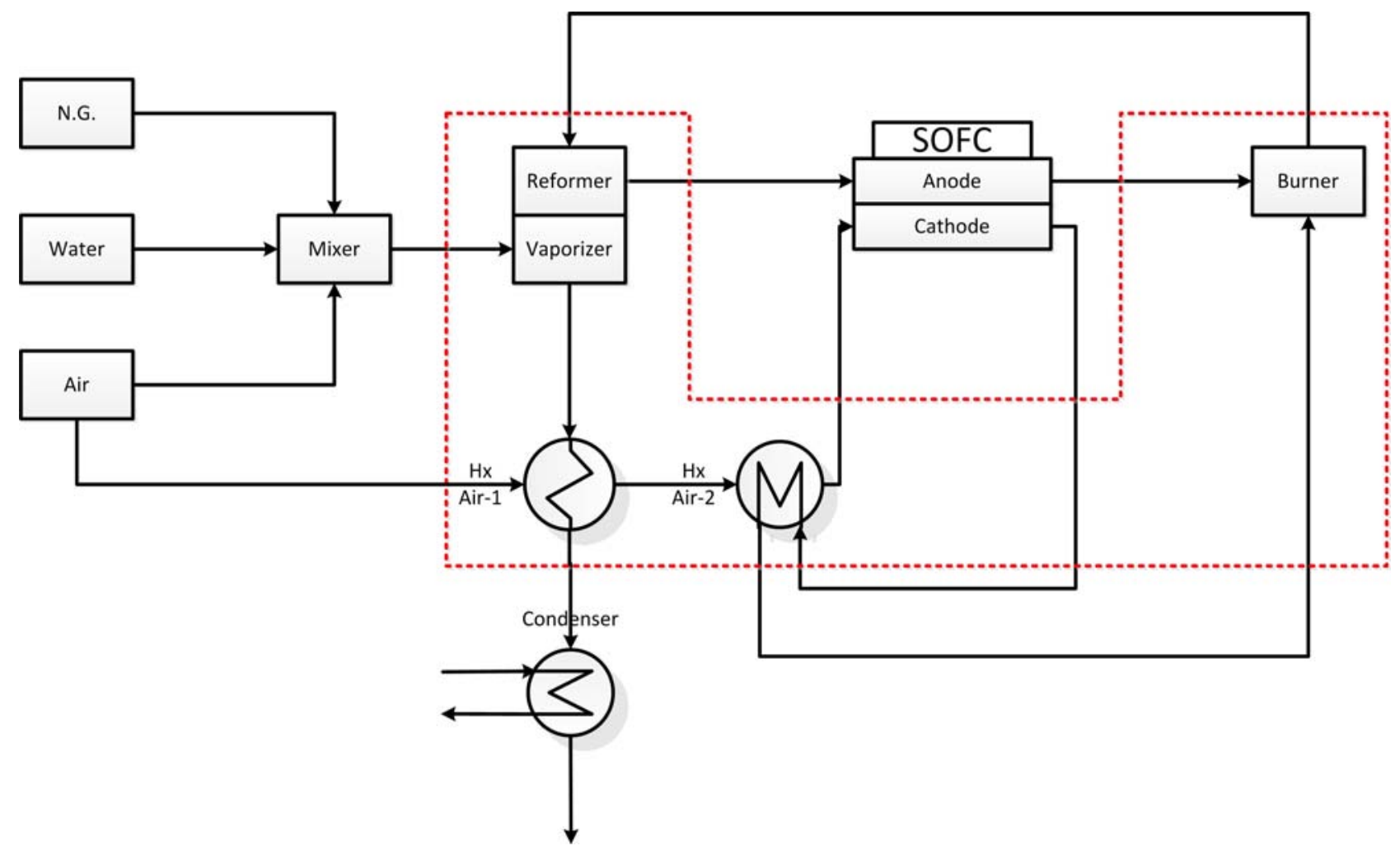

Fig. 1 Schematic of $\mathrm{kW}$ grade SOFC system experiment apparatus.

and an SOFC stack. The gas supply system includes air, hydrogen, nitrogen, methane and water. The major components of BOP are burner/reformer/heat exchanger, and an igniter. The cathode gas (air) is supplied by a blower and pre-heated to specified temperatures through the heat exchanger of BOP. Meanwhile, the water is vaporized to steam and then mixed with the fuel in the anode side. During the initial warm-up stage, the methane is supplied to after-burner to provide heat for the air and gas reformation. Some extra cooling air might be required to control the temperature of afterburner. The power conditioner is composed of a power switch device, converter, inverter, and AC/DC electric load. The power switch device offers basic protections such as overload defence, and anti-reverse current. A 36-cell stack is integrated onto the system.

A schematic sketch of after-burner/reformer/heat exchanger with the heat transport is shown in Fig. 2. It comprises a mixing chamber, a porous media section and reforming section. During normal operation, the flame is stable in the porous media zone. The remainders from the off-gas from the anode side of stack enter the afterburner to produce heat, which then provides the thermal energy required for the steam reforming and water gas shift reactions as well as to heat up the cathode air. The temperature of the afterburner is well controlled by properly in the test.

For the concerns of safety and long-term operation, the methodology of FEP (features, events and processes) is used to check relevant consequences of "what ifs" situation and find out proper remedy actions and thereafter are implemented into the operation and control logics. The programmable controlled is written by the LabVIEW 8.5, where the Real-Time Compact Rio (N.I. ${ }^{\circledR}$ ) is employed as the core of control system and linked by the local-internet to complete system control and data acquisitions.

\section{Results and Discussions}

This section presents the experimental results for the SOFC system at the start-up and after long-term 


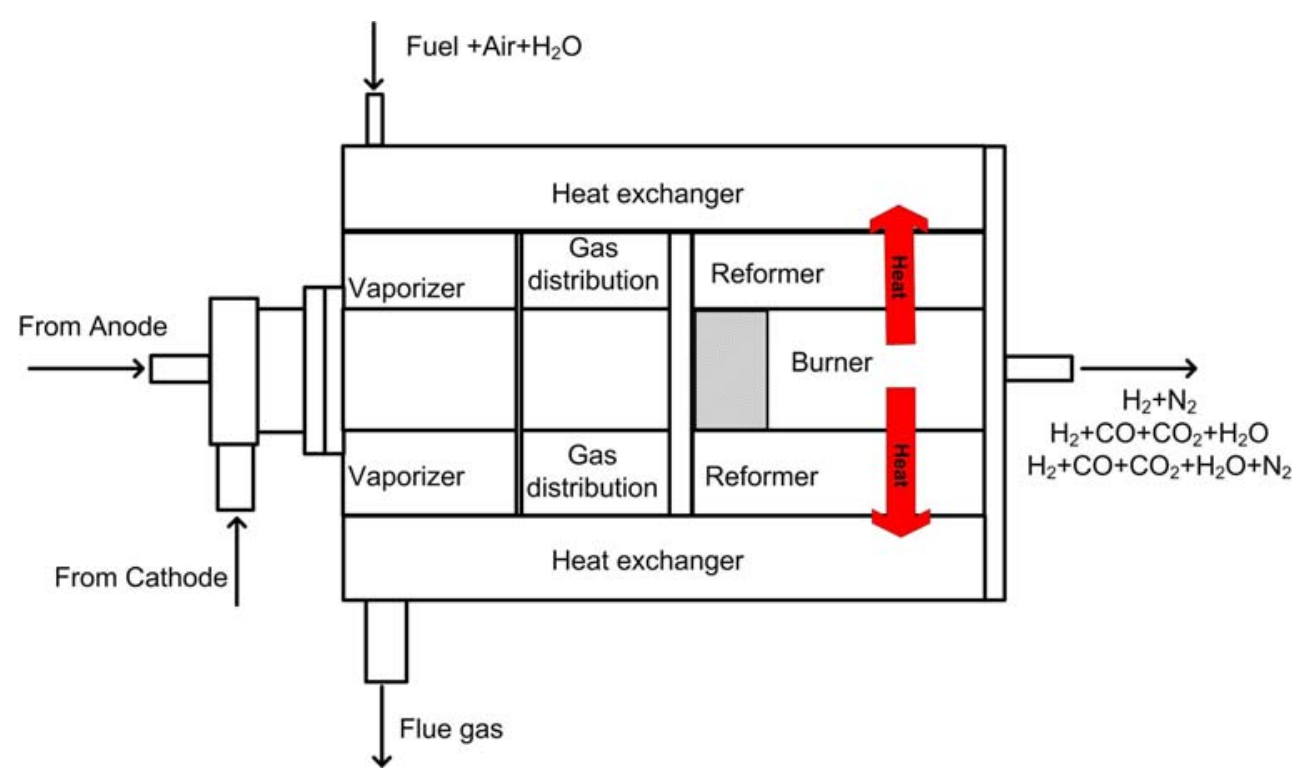

Fig. 2 Configuration of the after-burner/reformer/heat exchanger comprises a mixing chamber, a porous media, a reforming and a heat exchange section.

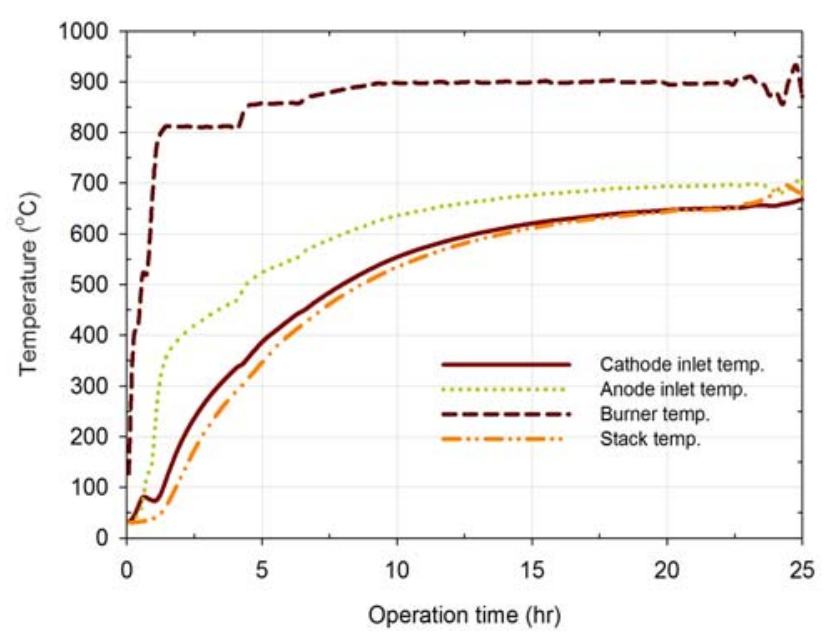

Fig. 3 Temperature profiles of different components during start up for an SOFC system.

normal operation, where the fuel is hydrogen or natural gas with auto-thermal or steam reforming. The temperature, voltage and gas concentration profiles of system, and the fuel utilization and system efficiency are presented.

\subsection{SOFC System Parameters and Profiles during} Start-up

Fig. 3 shows the variation of the temperature profiles from stacks and pipe lines. The operational parameters of stack, burner-outlet, anode and cathode-inlet temperature during start up process. The anode gas is hydrogen and nitrogen with 4.0 and 16.0 LPM (liters per minute), respectively. The flow rate of cathode gas is controlled at 40, 50 or 60 LPM step by step for start-up process. It indicates that the stack temperature is depended on cathode-inlet temperature, and the temperature profiles during start-up are similar. Fig. 4 presents the profiles of stack voltage and current with operation flow rate. During the start-up, the stack temperature increased degree is around $0.5{ }^{\circ} \mathrm{C} / \mathrm{min}$. When the stack temperature is about $500{ }^{\circ} \mathrm{C}$, the stack open circle voltage is 41.11 volts (1.14 V/cell) with $650{ }^{\circ} \mathrm{C}$. 


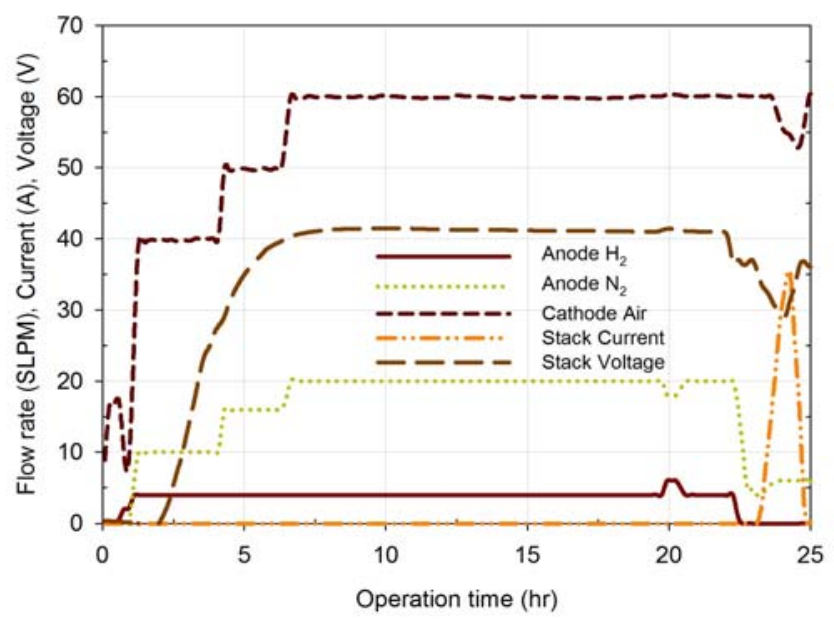

Fig. 4 Profiles of stack voltage, current and flow rates during start up for an SOFC system.

Table 1 The operation conditions, fuel utilization and system efficiency with different fuel operation.

\begin{tabular}{|c|c|c|c|c|c|}
\hline Exp. condition & $\begin{array}{l}\text { Exp. condition } \\
\text { Gas = LPM } \\
\mathrm{H}_{2} \mathrm{O}=\mathrm{cc} / \mathrm{min}\end{array}$ & $\begin{array}{l}\text { OCV } \\
(\mathrm{V})\end{array}$ & Stack power (W) & Fuel utilization (\%) & Electrical eff. (\%) \\
\hline $\begin{array}{l}\text { Dilute gas } \\
\mathrm{H}_{2}+\mathrm{N}_{2}\end{array}$ & $\begin{array}{l}\mathrm{H}_{2}=16 \\
\mathrm{~N}_{2}=13\end{array}$ & 42.35 & 933 (31A) & 53.13 & 36.0 \\
\hline $\begin{array}{l}\text { Reforming A } \\
\text { SR + POX + WGS }\end{array}$ & $\begin{array}{l}\mathrm{CH}_{4}=4.6 \\
\text { Air }=3.04 \\
\mathrm{H}_{2} \mathrm{O}=5.78\end{array}$ & 36.98 & $\begin{array}{l}1,060 \\
(36 \mathrm{~A})\end{array}$ & 67.16 & 45.0 \\
\hline $\begin{array}{l}\text { Reforming B } \\
\text { SR + WGS }\end{array}$ & $\begin{array}{l}\mathrm{CH}_{4}=4.6 \\
\mathrm{H}_{2} \mathrm{O}=6.8\end{array}$ & None & $\begin{array}{l}1,063 \\
(36 \mathrm{~A})\end{array}$ & 53.65 & 42.4 \\
\hline
\end{tabular}

\subsection{Normal Operation Condition}

In this stage, the dilute gas (hydrogen and nitrogen) or reformer gas (auto-thermal reforming or steaming reforming) is utilized as anode fuel. Before the system performance test, the reforming reactions are involved to produce hydrogen and carbon monoxide. The operation conditions, fuel utilization and system efficiency with different fuel operation are listed in Table 2. The system is heated up by the thermal energy from the afterburner. Validation test is carried out with the hydrogen as fuel to check its consistence with the result of stack testing. As the reformer of the system is operated with partial oxidation mode, the experimental data indicate the average stack temperature was $693^{\circ} \mathrm{C}$, and the current, stack voltage and power are $36 \mathrm{~A}, 29.48 \mathrm{~V}$, and $1,060 \mathrm{~W}$, respectively. The fuel utilization and electric efficiency are then calculated to be $67.16 \%$ and $45 \%$, respectively. Another test conditions, the power system is operated under steam reforming plus water gas shift reactions. In this case, the average stack temperature is $696{ }^{\circ} \mathrm{C}$. As the current is $36 \mathrm{~A}$, the average stack voltage and power were respectively 28.74 V and 1,063 W. Meanwhile, the fuel utilization and electric efficiency were $53.65 \%$ and $42.4 \%$, respectively. Fig. 5 illustrates the measured I-P-V curves with different of fuels in the test.

\subsection{Long-Term Operation}

Fig. 6 shows the variations of stack voltages, temperatures, power and reformate gas compositions during a 600-hour performance test. In the test, a constant current mode at 27 amperes is carried out. In high power operation (at 36 amperes), the unreacted methane concentration of reformate gas slightly increases to $9.8 \%$ in the test. The conversion rate of methane is $76.67 \%$. After 600 hours operation, the stack voltage is from 42.35 to 42.34 in the test. 


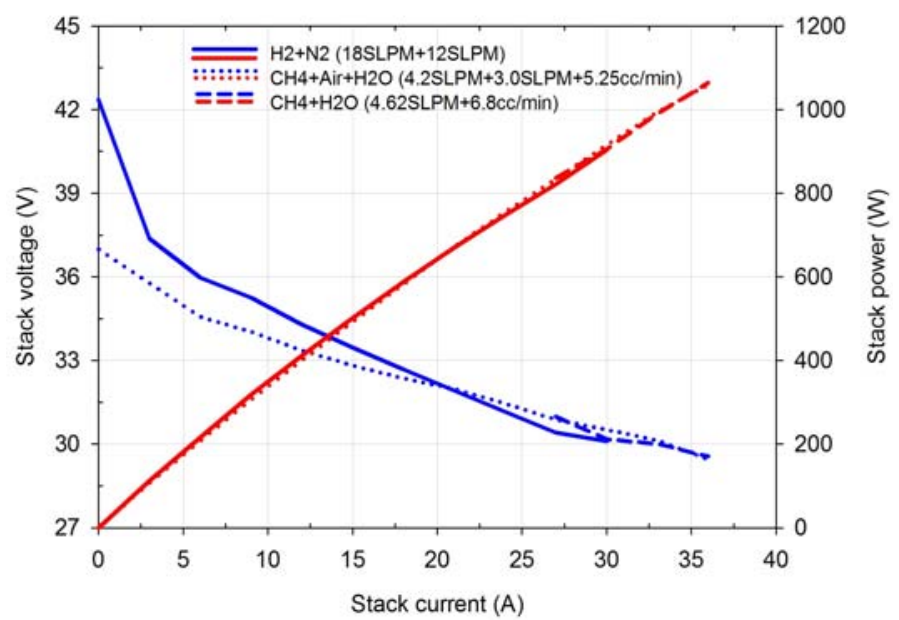

Fig. 5 The IVP curves with different fuels of $1 \mathrm{~kW}$ SOFC system.
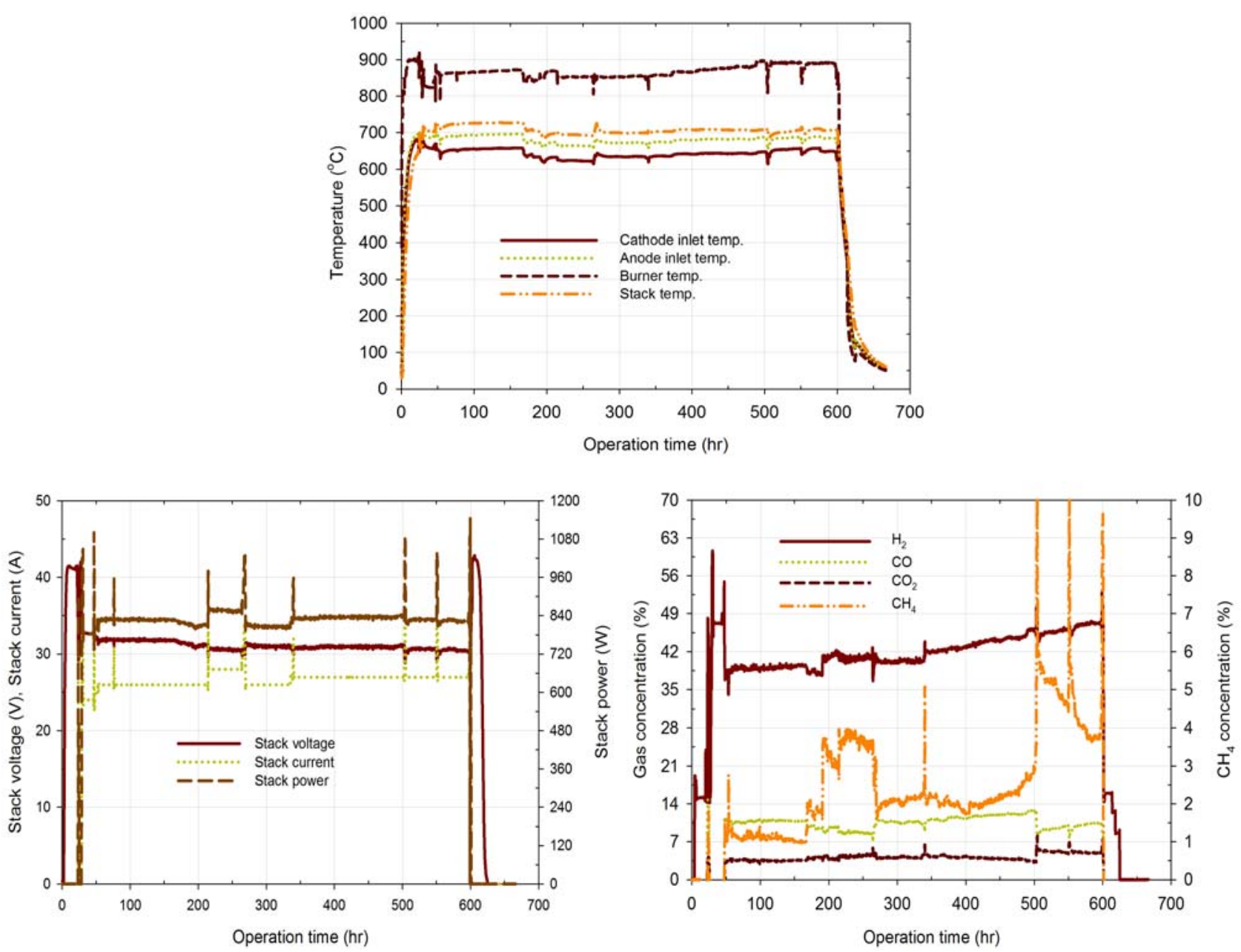

Fig. 6 The long-term variation of the stack voltage, temperature, power and reformate gas composition. 


\section{Conclusions}

Validation system performance tests for an SOFC power system are executed for over 600 hours performance tests execute with satisfactory performance. The system power is $1,060 \mathrm{~W}$ with auto-thermal reforming. The higher fuel utilization and electric efficiency are $67.16 \%$ and $45.30 \%$ LHV (lower heating value), respectively. A steady 650-hour system operation test was carried out at an average system temperature of $694{ }^{\circ} \mathrm{C}$. While, the current, voltage and output power are $26 \mathrm{~A}, 32.3 \mathrm{~V}$ and $840 \mathrm{~W}$, respectively, its electrical efficiency is around $33.4 \%$.

\section{References}

[1] Peters, R., Blum, L., Deja, R., Hoven, I., Tiedemann, W., Küpper, S., and Stolten, D. 2014. "Operation Experience with a 20 kW SOFC System.” Fuel Cells 14 (3): 489-99.

[2] Peters, R., Deja, R., Blum, L., and Hakala, T. 2013. "Analysis of Solid Oxide Fuel Cell System Concepts with Anode Recycling." International Journal of Hydrogen
Energy 38 (16): 6809-20.

[3] Halinen, M., Saariene, J., Noponen, M., Vinke, I. C., and Kiviaho, J. 2010. "Experimental Analysis on Performance and Durability of SOFC Demonstration.” Fuel Cells 10 (3): 440-52.

[4] Halinen, M., Thomann, O., and Kiviaho, J. 2012. "Effect of Anode Off-gas Recycling on Reforming of Natural Gas for Solid Oxide Fuel Cell Systems.” Fuel Cells 12 (5): 754-60.

[5] Lee, T. S., Chung J. N., and Chen, Y. C. 2011. "Design and Optimization of a Combined Fuel Reforming and Solid Oxide Fuel Cell System with Anode Off-gas Recycling." Energy Conversion and Management 52: 3214-26.

[6] Wahl, S., Segarra, A. G., Horstmann, P., Carre, M., Bessler, W. G., Lapicque, F., and Friedrich, K. A. 2015. "Modeling of a Thermally integrated $10 \mathrm{~kW}(\mathrm{e})$ Planar Solid Oxide Fuel Cell System with Anode Off-gas Recycling and Internal Reforming by Discretization in Flow Direction.” Journal of Power Sources 279: 656-66.

[7] Lo, S. K., Huang, C. N., Tan, H. I., Lin, C. H., Hong, W. T., and Lee, R. Y. 2014. "Validation System Performance Tests for a Kilowatt Grade SOFC System” 11th European SOFC \& SOE Forum, Lucerne Switzerland, July. 